\title{
Socio-Economic Conditions of Fishermen: Evidence from Hakaluki Haor of Bangladesh
}

\author{
Romaza Khanum
}

Assistant Professor, Department of Agricultural Economics and Policy, Sylhet Agricultural University, Sylhet-3100, Bangladesh

\begin{abstract}
The study explores the socio-economic conditions of fishermen in Hakaluki haor of Moulvibazar district. The main information was used in this regard to measure the poverty incidence such as family size, annual income, expenditure of food and non-food items, education level, etc. The study also estimates the poverty level by using CBN method. About 42 and $68 \%$ haor fishermen were below the lower and upper poverty lines respectively. The study suggests that the Government should take haor based policy to reduce poverty level of fishermen.
\end{abstract}

Key words: Haor Fishermen, Food-basket, Fisheries Resources, CBN Method, Poverty Incidence

\section{INTRODUCTION}

Rangladesh is a densely populated country of 147570 B $\mathrm{km} 2$ with 142.3 million people (BBS, 2011). It has extensive water resources in the form of ponds, lowlying natural depressions or haors and beels, oxbow lakes/baors, canals, rivers and estuaries covering an area of 4.64 million ha (DoF, 2009). Haor is, therefore, a highly productive natural source of livelihoods that support millions of poor people and plays a crucial role in supplying protein. Particularly, fishing communities secure their livelihoods from haor fisheries related activities such as capturing fish, fish trading, fish drying, aquatic life and net weaving.

In this study, Hakaluki haor is the largest haor, it covers administratively two district (Moulvibazar and Sylhet) and five upazila (subdistricts- Kulaura, Barlekha, Fenchugonj, Juri, and Golapgonj), with a complex system of more than 80 inter-connected beels which extends over 18,000 ha during the rainy season (IUCN, 2005), but during the dry season, the total area of beels becomes approximately 4600 ha and remains underwater for up to five to six months. The total area of the Hakaluki haor is 41613.83 ha (CWBMP-DOE-CNRS consortium 2005) composed mainly of wetland and the surrounding hillocks, reserve forest, planted forests, tea states and rubber plantations with 70000 ha floodplain area. In recent years, as a direct consequence of agricultural land expansion, haor area have shrunk or disappeared (Nishat, 1993).

The study area was covered in Kulaura Upazila under Moulvibazar district where flash floods, remoteness, infrastructure facilities are important factors of poverty. Along with these constraints, population pressure increases the landless household in the haor area (Khan and Islam, 2005). Haor fishermen are also more vulnerable due to ecological degradation, unsafe drinking water and sanitation, deforestation, lack of education institutions and communication facilities, inadequate livelihoods opportunities, and overall poor service provision (Anika, 2010). Christophe (2003:951) indicates as fishermen 'they are poor because they are fishermen and they are fishermen because they are poor' because they are characterized by overcrowded living conditions, low level of education, lack of alternative employment facilities, lack of skills, and politically powerlessness, etc.

The main purpose of this paper is to examine the socioeconomic conditions of the haor fishermen. It also determines the factors of poverty by measuring the incidences of poverty by using the Cost of Basic Needs method. Finally, it suggests policy recommendation for improving socio-economic conditions.

\section{Materials and Methods}

This research focuses on place-based case studies of a haor in Bangladesh, named Hakaluki haor. The study was conducted in Kulaura Upazila under Maulvibazar district. A multi-stage random sampling technique was considered. Two villages (i.e. Kandigaon and Radhanagar) and total 100 fishermen (50 haor fishermen from every village) were selected from this upazila. Structure and semi-structured interviews were conducted. Questionnaires, focus group discussions and key informant interviews were the main components of my tools which include various socioeconomic factors such as literacy rate, landholding, occupation, family size, sanitation, etc.

Cost of Basic Needs (CBN) method as the standard method was used for estimating the incidence of poverty. CBN entails a basket of food items based on consumption patterns and a reasonable allowance for non-food consumption. In this method, two poverty lines were estimated; a) lower poverty line and b) upper poverty line. For this, it is estimated with three variants such as poverty head count 
$\left(\mathrm{p}_{0}\right)$ which is a process of counting the poor on the consumption expenditure threshold in percentage term, poverty gap $\left(\mathrm{p}_{1}\right)$, and severity index $\left(\mathrm{p}_{2}\right)$. The data obtained from the field level, were analyzed by the using MS Excel, as per objectives of the study.

\section{Findings AND Discussion}

\subsection{SOCIO-ECONOMIC CONDITIONS OF HAOR FISHERMEN}

Socio-economic characteristics of haor fishermen are affected and influenced profoundly the development of individual behaviour and personality. It was obtained at individual level, variable comprises of age, education, main fishing activities, living condition, ownership of land (cultivated and homestead), etc. The family and its composition are related to fishing activities. Table 1 show that the average family size of fishermen was 6.13 persons, with 2.87 males and 1.91 females. It appears to be higher than the national average of 5.48 persons (BBS, 2009). The highest number of fishermen (28.5\%) was from 30 to 40 years age group but only $5 \%$ was above 50 years old.

Among the sample fishermen, $32 \%$ had no education. In the study, illiteracy rates were higher in poor fishermen compared to non-poor fishermen. Considering all the respondents, 57 and $11 \%$ had primary and secondary level of education. The fishing activities around Hakaluki haor were full time fishing, fish trading, fish drying and net making, where $59,24,7$, and $10 \%$ of respondents were full time fishermen, fish traders, fish dryer and fish net makers respectively (Fig.1). In terms of sanitary facilities, about $18 \%$ fishermen were using ring sanitary latrine. The source of lighting, only $30 \%$ had access to electricity and the large majority uses kerosene. All fishermen were using drinking water from tubewell but only $31 \%$ collected water from ponds, canal, and rivers for others household work (i.e. cooking, washing cloth, etc.). The ownership pattern of land (cultivated and homestead) was not well-off in the study area.

Table 1: Socio-Economic Characteristics of Haor Fishermen

\begin{tabular}{|c|c|c|c|}
\hline \multirow[t]{2}{*}{ Characteristics of Respondents } & \multicolumn{2}{|c|}{ Villages } & \multirow[t]{2}{*}{ Average } \\
\hline & $\begin{array}{l}\text { Kand } \\
\text { igaon }\end{array}$ & $\begin{array}{c}\text { Radha } \\
\text { nagar }\end{array}$ & \\
\hline Family Size (No.) & 5.47 & 6.78 & 6.13 \\
\hline \multicolumn{4}{|l|}{ Adult size of family member (No.) } \\
\hline Male & 3.17 & 2.56 & 2.87 \\
\hline Female & 1.93 & 1.89 & 1.91 \\
\hline \multicolumn{4}{|l|}{ Age (No.) } \\
\hline $30-40$ & 24 & 33 & 28.5 \\
\hline $41-50$ & 19 & 14 & 16.5 \\
\hline 50 and above & 7 & 3 & 5 \\
\hline Dependency Ratios & 66 & 54 & 60 \\
\hline \multicolumn{4}{|l|}{ Marital Status (\%) } \\
\hline Married & 68 & 54 & 61 \\
\hline Unmarried & 18 & 38 & 28 \\
\hline Divorce & 10 & 8 & 9 \\
\hline Others & 4 & - & 2 \\
\hline
\end{tabular}

Copyright (c) 2013, Asian Business Consortium | ABR

\begin{tabular}{|c|c|c|c|}
\hline \multicolumn{4}{|l|}{ Education level (\%) } \\
\hline Illiterate & 24 & 40 & 32 \\
\hline Primary & 62 & 52 & 57 \\
\hline Secondary & 14 & 8 & 11 \\
\hline \multicolumn{4}{|l|}{ Fishing Activities (\%) } \\
\hline fishing & 50 & 68 & 59 \\
\hline Fish trading & 26 & 22 & 24 \\
\hline Fish drying & 10 & 4 & 7 \\
\hline Net making & 14 & 6 & 10 \\
\hline \multicolumn{4}{|l|}{ Sanitary Facilities (\%) } \\
\hline Sanitary & 20 & 15 & 17.5 \\
\hline Slab & 80 & 85 & 82.5 \\
\hline \multicolumn{4}{|l|}{ Lighting (\%) } \\
\hline Electricity & 30 & 42 & 36 \\
\hline Kerosene & 70 & 58 & 64 \\
\hline \multicolumn{4}{|l|}{ Water (\%) } \\
\hline Drinking water & 100 & 100 & 100 \\
\hline others & 38 & 24 & 31 \\
\hline \multicolumn{4}{|l|}{ Ownership of cultivated land (\%) } \\
\hline Landless & 70 & 68 & 69 \\
\hline Own & 30 & 32 & 31 \\
\hline \multicolumn{4}{|l|}{ Ownership of Homestead land (\%) } \\
\hline Landless & 78 & 82 & 80 \\
\hline own & 22 & 18 & 20 \\
\hline \multicolumn{4}{|l|}{ Roof Material of Dwelling House } \\
\hline Straw/Leaves/Grass & 38 & 34 & 36 \\
\hline Tin/Brick & 62 & 66 & 64 \\
\hline
\end{tabular}

Source: Field survey, 2012

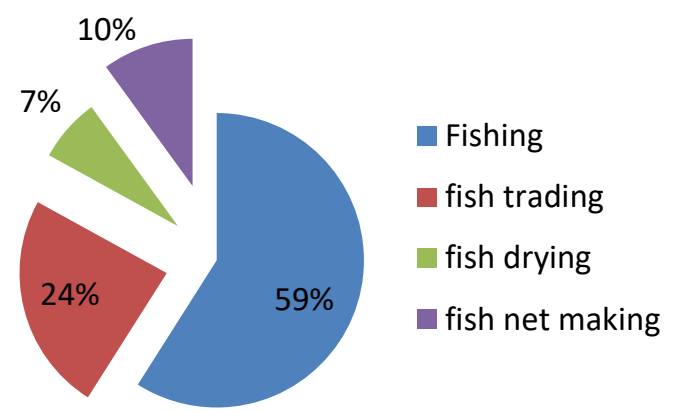

Fig.1: Main Fishing Activities in the Study Area

Table 2: Poverty Status of Haor Fishermen based on Annual Income

\begin{tabular}{|l|c|c|}
\hline Poverty Status & Annual Income (Tk.) & Percentage (\%) \\
\hline Very poor & Less than $40,000-75,000$ & 31 \\
\hline Poor & $80,000-140,220$ & 53 \\
\hline Non-poor & $156,000-2,00000$ & 16 \\
\hline
\end{tabular}

Source: Field survey, 2012

In the study area, fishermen's income mainly depend on haor fisheries resources. In terms of annual income, Table 2 shows that 53 and $16 \%$ of respondent were poor and non-poor respectively. Of the former, 69 and $80 \%$ respondents were landless. It implies that all landless fishermen were not poor. 
Table 3: Poverty Status of Haor Fishermen based on Monthly Expenditure

\begin{tabular}{|l|c|c|}
\hline Poverty Status & $\begin{array}{c}\text { Monthly } \\
\text { Expenditure (Tk.) }\end{array}$ & Percentage \\
\hline Poor & 936.98 & 73 \\
\hline Non-poor & 1535.76 & 27 \\
\hline
\end{tabular}

Source: Field Survey, 2012

From Table 3, per capita expenditure of poor and nonpoor were $73 \%$ and $27 \%$ respectively, whereas per capita expenditure of the poor is Tk. 1064.92 at national level (BBS, 2010). It is estimated that per capita expenditure of poor is higher at national level.

\subsection{INCIDENCE OF POVERTY}

The monthly per capita 'maximum' and 'minimum' food expenditure had been estimated as Tk. 554.83 and Tk. 409.93 respectively. The most of the fishermen had monthly expenditure between Tk. 3000 to Tk. 12,000 where the share of non-food expenditure was only $22.7 \%$. It was, therefore, found that monthly expenditure of food consumption were higher than non-food items, which includes clothing, housing, medicine, fuel, lighting and education, etc.

Table 4: Incidence of Poverty by CBN Method

\begin{tabular}{|l|c|c|}
\hline \multicolumn{1}{|c|}{ Poverty Measures } & $\begin{array}{c}\text { Lower } \\
\text { Poverty line }\end{array}$ & $\begin{array}{c}\text { Upper } \\
\text { Poverty Line }\end{array}$ \\
\hline $\begin{array}{l}\text { Head Count Ratio } \\
\text { (Incidence of Poverty) }\end{array}$ & 42.52 & 68.17 \\
\hline $\begin{array}{l}\text { Poverty Gap } \\
\text { (Depth of poverty) }\end{array}$ & 11.53 & 20.14 \\
\hline $\begin{array}{l}\text { Square Poverty Gap } \\
\text { (Severity of Poverty) }\end{array}$ & 3.90 & 3.59 \\
\hline
\end{tabular}

Source: Field Survey, 2012

For the study, the incidence of poverty line was estimated by CBN method. About $68.17 \%$ was Head Count Ratio, the depth of poverty (P1) and severity of poverty (P2) were $20.14 \%$ and $3.59 \%$ (Table 2 ) respectively. Moreover, there were no significant difference between estimated the poverty line and the incidence poverty curve (Fig. 2). It was a positive relationship between per month expenditure and cumulative percentage of population.

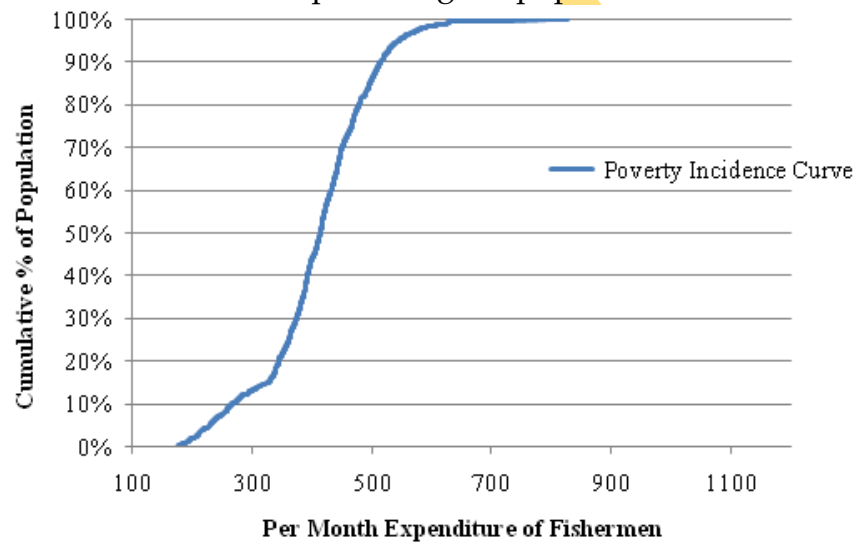

Fig. 2: Measurement of Poverty Line

\section{ConClusion}

These findings lead to establish a number of the following implications for sustainable livelihoods in haor area; I) to build a more effective institution, local institutions need to co-operate and work closely with haor fishermen. More specifically, local institutions should enhance their providing support services, understanding of the linkage between articulation and access to resources, and improving mediating role like information method, financial support, technological knowledge, leadership and gender focus; II) the government needs to come forward to ensure economic safety nets, and improve management policies of the haor resources. Moreover financial support of respective department will be influenced on small-scale business, diverse farming and specific haor based off-farm activities.

\section{REFERENCES}

Anika, T. (2011) "Save Haor Areas: Creating Awareness Among the Youth" The Daily Star, http://www.thedailystar.net, (Last Consulted May. 2012).

BBS (2009) "Report of the Household Expenditure Survey 2006" Statistical Division, Ministry of Planning, Government of Bangladesh, Dhaka.

BBS (2010) "Measurement of Poverty" Chapter-VI, www.bbs.gov.bd (Last consulted June 2012)

BBS (2011) "Population \& Housing Census 2011: Preliminary Result", Bangladesh Bureau of Statistics, Statistical Yearbook of Bangladesh, Planning Division, Ministry of Planning, Dhaka, Bangladesh.

Christophe, B. (2003) "When Fishery Rhymes With Poverty: A First Step Beyond the Old Paradigm on Poverty in Small-scale Fisheries" World Development, Vol. 31(6): 949-975.

CWBMP-DOE-CNRS Consortium (2005) "Baseline Survey of Hakaluki Haor" Dhaka, Bangladesh.

DoF (2009) "Development Project", Department of Fisheries, http://www.fisheries.gov.bd, Government of the People's Republic of Bangladesh, Dhaka, Bangladesh.

IUCN (2005) "A Plan for Sustainable Wetland Resource Management" IUCN Bangladesh Country Office, Dhaka.

Khan, M.I. and Islam, M.A. (2005) "Poverty Status of a Critical Wetland Area: Hakaluki Haor" In A. Nishat, S.M. Monjurul, H. Khan, and R. Ahmed (eds.), The World Conservation Union, Bangladesh Country Office.

Nishat, A. (1993) "Freshwater Wetlands in Bangladesh: Status and Issues" In Nishat, A., Hussain, Z., Roy, M.K. and Karim, A. (eds.) Freshwater Wetlands in Bangladesh-Issues and Approaches for Management, IUCN, Gland, Switzerland, 75-104.

$$
--0--
$$

